\title{
Assessment of Radiological Hazard Indices from Exposures to Background lonizing Radiation Measurements in South-South Nigeria
}

\author{
Godwin Ekong, 2, *, Timothy Akpa ${ }^{1,2}$, Ibrahim Umaru ${ }^{2}$, Williams Lumbi ${ }^{2}$, Mbet Akpanowo, ${ }^{1,2}$ \\ Nsikak Benson ${ }^{3}$
}

${ }^{1}$ Nigeria Nuclear Regulatory Authority, Abuja, Nigeria

${ }^{2}$ Department of Physics, Nasarawa State University, Keffi, Nigeria

${ }^{3}$ Department of Chemistry, Covenant University, Ota, Nigeria

Email address:

godwin.ekong@nnra.gov.ng (G. Ekong)

*Corresponding author

\section{To cite this article:}

Godwin Ekong, Timothy Akpa, Ibrahim Umaru, Williams Lumbi, Mbet Akpanowo, Nsikak Benson. Assessment of Radiological Hazard Indices from Exposures to Background Ionizing Radiation Measurements in South-South Nigeria. International Journal of Environmental Monitoring and Analysis. Vol. 7, No. 2, 2019, pp. 40-47. doi: 10.11648/j.ijema.20190702.11

Received: August 5, 2019; Accepted: August 22, 2019; Published: September 5, 2019

\begin{abstract}
Radioactivity in the environment from sources of natural and human activities resulting in planned, emergency and existing exposure to human population, environment and other biota has led to growing apprehensions in Nigeria and the world. The existing exposure situations mainly from natural radionuclides, present in the earth crust from creation emits background ionizing radiation leading to gamma dose exposures. The objective of this study was to assess the background ionizing radiation and associated radiological hazard indices in Itu, Nigeria located at 5010'0" N 7059'0" E, and establish an eco-radiological baseline data prior to the construction of any nuclear fission reaction facility in the area. A systematic random method of measurement was employed within demarcated monitoring zones of entire geological map of Itu, Nigeria. The global positioning system finder (GARMIN Etrex 10) was used for data point location, while RDS-31S/R Multi-purpose survey meter was used for dose rate measurement. The background ionizing radiation measurement obtained ranged from $0.041 \pm 0.002-0.045 \pm 0.002$ $\mu \mathrm{Sv} / \mathrm{hr}$ with overall mean of $0.042 \pm 002 \mu \mathrm{Sv} / \mathrm{hr}$, which was lower than the world mean of $0.2 \mu \mathrm{Sv} / \mathrm{hr}$. Radiological hazard indices arising from the background ionizing radiation measurement were also evaluated. The mean estimated Gamma Dose Rate was $9.312 \mathrm{nGy} / \mathrm{hr}$, the terrestrial outdoor Annual Effective Dose Rate arising from gamma was $6.83 \mathrm{mSv} / \mathrm{yr}$, that of indoor was $21.85 \mathrm{mSv} / \mathrm{yr}$ and Excess Life Cancer Risk was $0.05 \times 10^{-3}$. The mean evaluated radiological hazard indices were found to be below admissible limits, and thus poses no significant radiological health threat to the populace. Therefore, the assessment demonstrates that there is no elevated level of dose rate, which is makes it safe for human habitation, but care should be taken to avoid increase radiation level from human activities. It is recommended that constant radiological monitoring be encourage, and the data considered as radiological baseline in Itu, Nigeria.
\end{abstract}

Keywords: Background Ionizing Radiation, Dose Rate, Hazard Indices, Radionuclides Concentration, Nigeria

\section{Introduction}

There are increasing concerns over the exposure of the human population to enhanced ionizing radiations emanating from natural and anthropogenic sources [1-8]. In the terrestrial environment, humans are mainly exposed to ionizing radiations through medical applications [9], accidents or emergency occurrence at nuclear power plants (NPPs), tests of nuclear weapons and radiotoxic radionuclides from refurbished nuclear plants [8]. Besides the releases from these anthropogenic channels, long-term exposures through plant uptake from agricultural soil and subsequent bioaccumulation and localized contamination of plants and food produce [2, 10-13], and portable water and wastewater treatment plants have been documented [14]. 
Planned, emergency and existing exposure has been considered as the major types of exposure situations. The planned exposure situation occur due to planned introduction or operation of radiation sources from justified practice, while an emergency exposure situations takes place as a result of incident during a planned operation or simply when planned operation gets out of control. However, existing exposures situations are mainly caused by natural background radiations that already exist in the earth crust and actions need to be taken [15-17]. The natural background radiation in the environment is mostly contributed by natural occurring radioactive materials which are classified into primordial (such as ${ }^{40} \mathrm{~K},{ }^{232} \mathrm{Th},{ }^{235} \mathrm{U}$ and ${ }^{238} \mathrm{U}$ ), cosmogenic (e.g. ${ }^{7} \mathrm{Be},{ }^{14} \mathrm{C}$ and ${ }^{3} \mathrm{H}$ ), and are found in the earth crust, soil, water, and the atmosphere as well as almost every living thing [15, 18, 19]. Anthropogenically radioactive substances that are released into the environment poses serious environmental and ecological challenges due to their persistency in the environment [20-22]. Primordial or terrestrial radionuclides are naturally occurring radioactive materials that emanate from the Earth's crust and mantle; the cosmogenic radionuclides arise from the atmospheric interactions between various gases and cosmic rays.

Anthropogenic radionuclides come from a variety of human activities such as fallouts associated with nuclear plants accidents or global depositions from nuclear weapons tests resulting in concentration of Technically Enhanced Naturally
Occurring Radioactive Material (TENORM) in the products and by-products of the activities. These TENORM are but not limited to: exploration and exploitation of oil and gas, energy production (coal), mining and milling of ores, metal recycling/steel processing plants, water and waste treatment, resources extraction, and some consumer products and nuclear reaction activities and facilities. Therefore, the background ionizing radiation (BIR) is radiation of man's natural environment, which is made of what emanates from cosmic rays, the naturally radioactive elements of the earth and human body and its activities [23]. These exposures contribute immensely in enhancing the level of BIR, which globally averages $2.4 \mathrm{mSv} / \mathrm{y}$ annual effective dose [24, 25].

This study became imperative due to a proclamation made on choosing some candidate sites for constructing NPP facilities and corresponding activities in Nigeria which Itu, and Geregu, Nigeria amongst others were listed [26, 27]. Therefore, the aim of this study was to evaluate the eco radiological baseline, which could provide necessary radiological data and make invaluable input to knowledge prior to the construction of any nuclear fission reaction facility. This study will provide baseline information and stopgap check for future build-up of radiation level values that could arise from operation of such facility and offer public reassurance as regards to current environmental radiation level to the populace.

\section{Materials and Methods}

\subsection{Study Area}

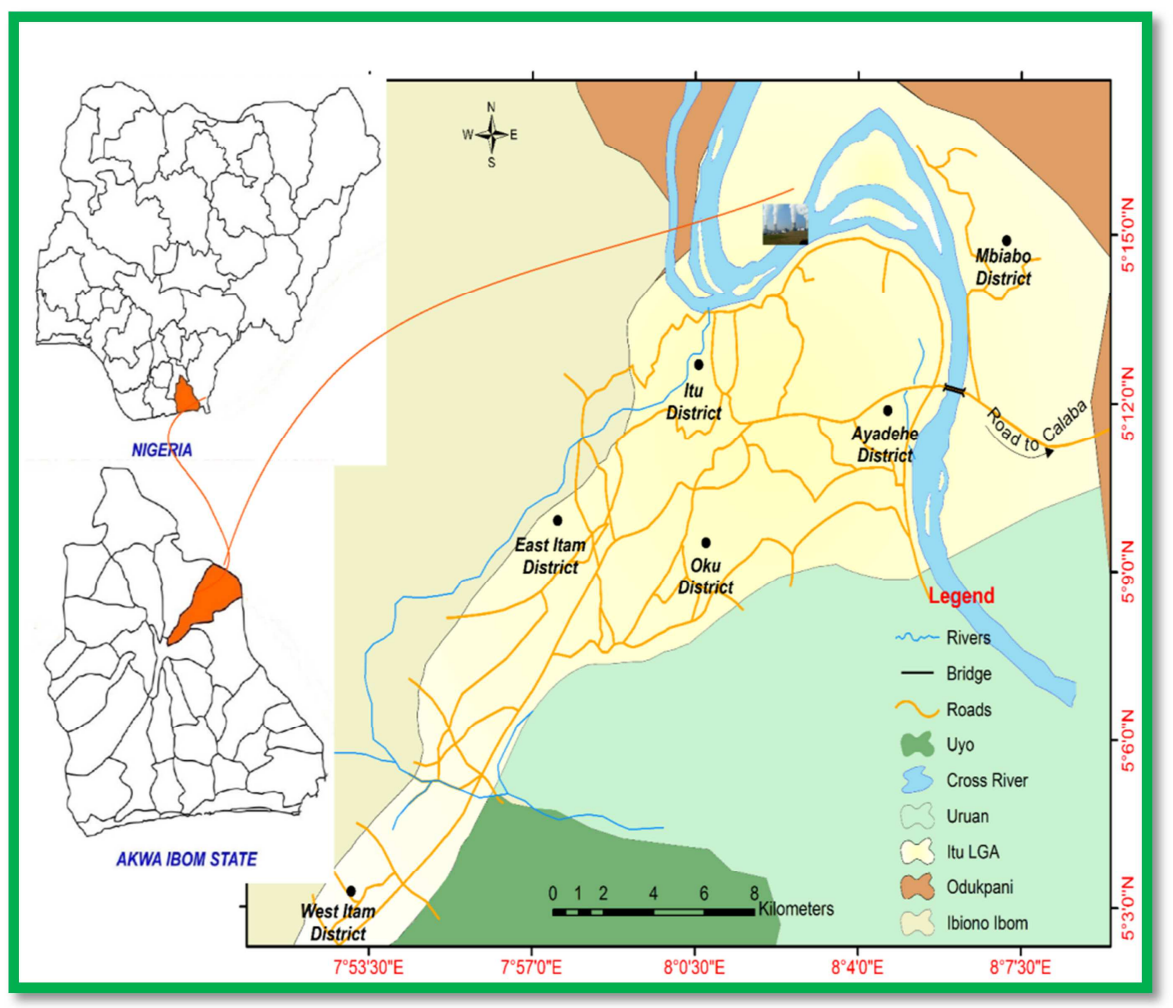

Figure 1. A 2-Dimensional Arc-GIS Map of the study area (Insert: Map of Nigeria \& Akwa Ibom State). 
The study area is Itu, Nigeria, located within the coordinates of 5010'0 N 7059'0"E as presented in Figure 1. It is a Local Government Area in Akwa Ibom State, Southern Nigeria. The projected population as at 2013 was put at 161,572 and the major occupation of mainly of farming, fishing and trading. It is bounded by four villages/LGAs from North by Eki/Odukpani of Cross River State; South by Uyo, East by Anakpa/Uruan and West by Oko Ita/ Ibiono Ibom all in Akwa Ibom State. The climate of Itu like Nigeria generally is categorized as tropical climate, which is further classified into rainy and dry season. The rainy season could experience averaged $2409 \mathrm{~mm}$ annual precipitation with mean air surface temperatures ranging between $25.5-28.3^{\circ} \mathrm{C}$ [28].

\subsection{Background Radiation Measurements}

The global positioning system (GPS) - GARMIN Etrex 10 (Serial number 3964) was used to designate the data point coordinates prior to dose rate measurements, and RDS-31S/R Multi-purpose survey meter with serial number 2100372 was used for dose rate measurements, which has the ability to display in dose rate $\mathrm{uSv} / \mathrm{hr}$ and $\mu \mathrm{R} / \mathrm{hr}$. The BIR measurement was conducted according to the NPP radiological monitoring demarcated zones span over the six districts of Itu, Nigeria, and segmented in accordance with NPP radiological monitoring plan. These are: Exclusive Zone at $1.5 \mathrm{~km}$ from the major river, Sterilized Zone at $5 \mathrm{~km}$, Emergency Planning Zone at $16 \mathrm{~km}$, Impact Assessment Zone at $30 \mathrm{~km}$ and measurements conducted $5 \mathrm{~km}$ bounded around Itu, L.G.A as presented in Figure 2 [29].

Prior to the monitoring exercise, a pre-operational / functionality and quality checks prior to BIR measurement were performed on the equipment to ensure their effective, accurate and perfect working conditions [15]. Upon the location of each survey unit/data point, BIR measurements were conducted through a process of scanning around $360^{\circ}$ with survey meter at each data points before taking reading at 1 meter from ground. A Total of 255 measurements were recorded, averaged from 51 data points in the four radiological monitoring zones entire study area, and at $5 \mathrm{~km}$ impact distance to serve as control. These dose rate measurements are presented in Table 1.

\subsection{Evaluation of Hazard Indices}

\subsubsection{Gamma Dose Rate (D)}

The BIR measurements recorded were used to estimate radiological hazard indices as presented in Table 1. Gamma shine due to surface-dwelling gamma rays measured at $1 \mathrm{~m}$ from the ground was used to determine gamma dose rate by using the expression [30]:

$$
D=\left[1_{\mu R / h r}=\frac{8.7_{n G y}}{h r}\right]=\frac{8.7 \times 10^{-3}}{1 / 8760} \mu G y y^{-1}=76.212 \mu G y y^{-1}
$$

\subsubsection{Annual Effective Dose Rate (AEDE)}

However, the annual effective dose equivalent estimations are calculated from gamma dose rate with a conversion factor of $0.7 \mathrm{~Sv} / \mathrm{Gy}$ of absorbed dose in air to effective dose an adults receives and $20 \%$ time out-of-doors ( $80 \%$ indoors) using equation $2[31,32]$ :

$$
\mathrm{AEDE}_{\mu \mathrm{Sv}}=\mathrm{D}_{\mathrm{nGy} / \mathrm{h}} \times 8760_{\mathrm{h} / \mathrm{y}} \times 0.2 \times 0.7 \mathrm{~Sv} / \mathrm{Gy} \times 10^{-3}
$$

\subsubsection{Excess Life Cancer Risk (ELCR)}

In addition, the ELCR was determined from the annual effective dose rate with duration of life (DL) estimated as 70 years for children and 50 years for adult. The risk factor (RF, $5 \%$ ) for public exposure considered to produce stochastic effect is given as [33, 34].

$$
\mathrm{ELCR}_{\mathrm{mSv} / \mathrm{y}}=\mathrm{AEDE}_{\mathrm{mSv} / \mathrm{y}} \times \mathrm{RF} \times \mathrm{DL}
$$

\begin{tabular}{|c|c|c|c|c|c|c|}
\hline Location & $\begin{array}{l}\text { Measurement } \\
(\mu \mathrm{Sv} / \mathrm{hr})\end{array}$ & $\begin{array}{l}\text { Abs. Dose } \\
(\mu \mathrm{R} / \mathrm{hr})\end{array}$ & $\begin{array}{l}\text { Gamma Dose } \\
\text { Rate (nGy/y) }\end{array}$ & $\begin{array}{l}\text { AEDR (Out) } \\
(\mathrm{mSv} / \mathrm{yr})\end{array}$ & $\begin{array}{l}\text { AEDR (IN) } \\
(\mathrm{mSv} / \mathrm{yr})\end{array}$ & $\begin{array}{l}\text { ELCR } \\
\times 10^{-3} \\
\end{array}$ \\
\hline \multicolumn{7}{|l|}{ EXCLUSIVE ZONE } \\
\hline Akpa Ekpene Oton & 0.042 & 0.012 & 9.262 & 14.20 & 45.44 & 0.05 \\
\hline Obio Inwang Itu & 0.045 & 0.013 & 9.923 & 15.21 & 48.68 & 0.05 \\
\hline Ikot Efa & 0.045 & 0.013 & 9.923 & 15.21 & 48.68 & 0.05 \\
\hline Ayadehe Quarry & 0.041 & 0.012 & 9.041 & 13.86 & 44.35 & 0.05 \\
\hline Mbiabo Ikot Edem & 0.043 & 0.012 & 9.482 & 14.54 & 46.52 & 0.05 \\
\hline Mbiabo Edera & 0.041 & 0.012 & 9.041 & 13.86 & 44.35 & 0.05 \\
\hline Mbiabo Abasi Efiori & 0.042 & 0.012 & 9.626 & 14.76 & 47.22 & 0.05 \\
\hline Ikot Essien Ekpe Inyang & 0.041 & 0.012 & 9.041 & 13.86 & 44.35 & 0.05 \\
\hline Mkpana Uruk & 0.041 & 0.012 & 9.041 & 13.86 & 44.35 & 0.05 \\
\hline AVERAGE & 0.042 & 0.012 & 9.626 & 14.76 & 47.22 & 0.05 \\
\hline \multicolumn{7}{|l|}{ STERILIZED ZONE } \\
\hline Itu & 0.042 & 0.012 & 9.626 & 14.76 & 47.22 & 0.05 \\
\hline Edem Nnwosu & 0.041 & 0.012 & 9.041 & 13.86 & 44.35 & 0.05 \\
\hline Afia Isong & 0.041 & 0.012 & 9.041 & 13.86 & 44.35 & 0.05 \\
\hline Leper Settlement Colony & 0.042 & 0.012 & 9.626 & 14.76 & 47.22 & 0.05 \\
\hline Mbak Atai & 0.041 & 0.012 & 9.041 & 13.86 & 44.35 & 0.05 \\
\hline Afaha Ikot Udo & 0.041 & 0.012 & 9.041 & 13.86 & 44.35 & 0.05 \\
\hline Okopodi Itu & 0.042 & 0.012 & 9.626 & 14.76 & 47.22 & 0.05 \\
\hline Ikot Nya & 0.041 & 0.012 & 9.041 & 13.86 & 44.35 & 0.05 \\
\hline Obot Itu & 0.041 & 0.012 & 9.041 & 13.86 & 44.35 & 0.05 \\
\hline
\end{tabular}

Table 1. BIR measurements and the estimated hazard indices from of the study area. 


\begin{tabular}{|c|c|c|c|c|c|c|}
\hline Location & $\begin{array}{l}\text { Measurement } \\
(\mu \mathrm{Sv} / \mathrm{hr})\end{array}$ & $\begin{array}{l}\text { Abs. Dose } \\
(\mu \mathrm{R} / \mathrm{hr})\end{array}$ & $\begin{array}{l}\text { Gamma Dose } \\
\text { Rate (nGy/y) }\end{array}$ & $\begin{array}{l}\text { AEDR (Out) } \\
(\mathrm{mSv} / \mathrm{yr})\end{array}$ & $\begin{array}{l}\text { AEDR (IN) } \\
(\mathrm{mSv} / \mathrm{yr})\end{array}$ & $\begin{array}{l}\text { ELCR } \\
{\mathrm{x} 10^{-3}}^{-3}\end{array}$ \\
\hline AVERAGE & 0.041 & 0.012 & 9.041 & 13.86 & 44.35 & 0.05 \\
\hline \multicolumn{7}{|c|}{ EMERGENCY PLANNING ZONE } \\
\hline Obot Etim & 0.042 & 0.012 & 9.626 & 14.76 & 47.22 & 0.05 \\
\hline Obot Itu & 0.043 & 0.012 & 9.482 & 14.54 & 46.51 & 0.05 \\
\hline Ikot Uso Akpan & 0.042 & 0.012 & 9.626 & 14.76 & 47.22 & 0.05 \\
\hline Ikot Eka Iko & 0.041 & 0.012 & 9.041 & 13.86 & 44.35 & 0.05 \\
\hline Ikot Ntuen Oku & 0.041 & 0.012 & 9.041 & 13.86 & 44.35 & 0.05 \\
\hline Adang Itam & 0.042 & 0.012 & 9.626 & 14.76 & 47.22 & 0.05 \\
\hline Ekim Itam & 0.041 & 0.012 & 9.041 & 13.86 & 44.35 & 0.05 \\
\hline Ema Itam & 0.041 & 0.012 & 9.041 & 13.86 & 44.35 & 0.05 \\
\hline Ikot Annie & 0.042 & 0.012 & 9.626 & 14.76 & 47.22 & 0.05 \\
\hline Ikot Andem & 0.041 & 0.012 & 9.041 & 13.86 & 44.35 & 0.05 \\
\hline Ikot Anen Atai & 0.043 & 0.012 & 9.482 & 14.54 & 46.51 & 0.05 \\
\hline \multicolumn{7}{|c|}{ IMPACT ASSESSMENT ZONE } \\
\hline Ibiaku Ikot Obong & 0.042 & 0.012 & 9.626 & 14.76 & 47.22 & 0.05 \\
\hline Ikot Ayan & 0.041 & 0.012 & 9.041 & 13.86 & 44.35 & 0.05 \\
\hline Ikot Ukono & 0.041 & 0.012 & 9.041 & 13.86 & 44.35 & 0.05 \\
\hline Mbiabong Afaha & 0.042 & 0.012 & 9.626 & 14.76 & 47.22 & 0.05 \\
\hline Uyo Itam & 0.041 & 0.012 & 9.041 & 13.86 & 44.35 & 0.05 \\
\hline Ikot Ebom Itam & 0.041 & 0.012 & 9.041 & 13.86 & 44.35 & 0.05 \\
\hline Ikot Ekwere Itam & 0.042 & 0.012 & 9.626 & 14.76 & 47.22 & 0.05 \\
\hline Ikot Obong Erong & 0.041 & 0.012 & 9.041 & 13.86 & 44.35 & 0.05 \\
\hline Mbribit Itam & 0.041 & 0.012 & 9.041 & 13.86 & 44.35 & 0.05 \\
\hline Nung Ukot Itam & 0.042 & 0.012 & 9.626 & 14.76 & 47.22 & 0.05 \\
\hline AVERAGE & 0.041 & & 9.041 & 13.86 & 44.35 & 0.05 \\
\hline Overall Average & 0.042 & & 9.312 & 6.83 & 21.85 & 0.05 \\
\hline
\end{tabular}

\section{Results}

\subsection{Data Presentation}

The BIR measurement values recorded from demarcated radiological monitoring zones as well as at $5 \mathrm{~km}$ from Itu, LGA are presented in Table 1 and Figures 2 and 3 presents a 3-Dimensional Arc-GIS Map showing the BIR measurements of Itu, Nigeria and the world limit on a demarcated radiological monitoring zones as stated in Paragraph 2.2. The BIR measurement values recorded for the entire four zones of Itu LGA were $(0.041 \pm 0.002-0.045 \pm 0.002) \mu \mathrm{Sv} / \mathrm{hr}$ with an overall average dose rate of $0.042 \pm 002 \mu \mathrm{Sv} / \mathrm{hr}$. The average BIR value was found be lower than world average dose rate value of $0.2 \mu \mathrm{Sv} / \mathrm{hr}$ which indicated no human activity for increase radiation level $[15,17,35]$.

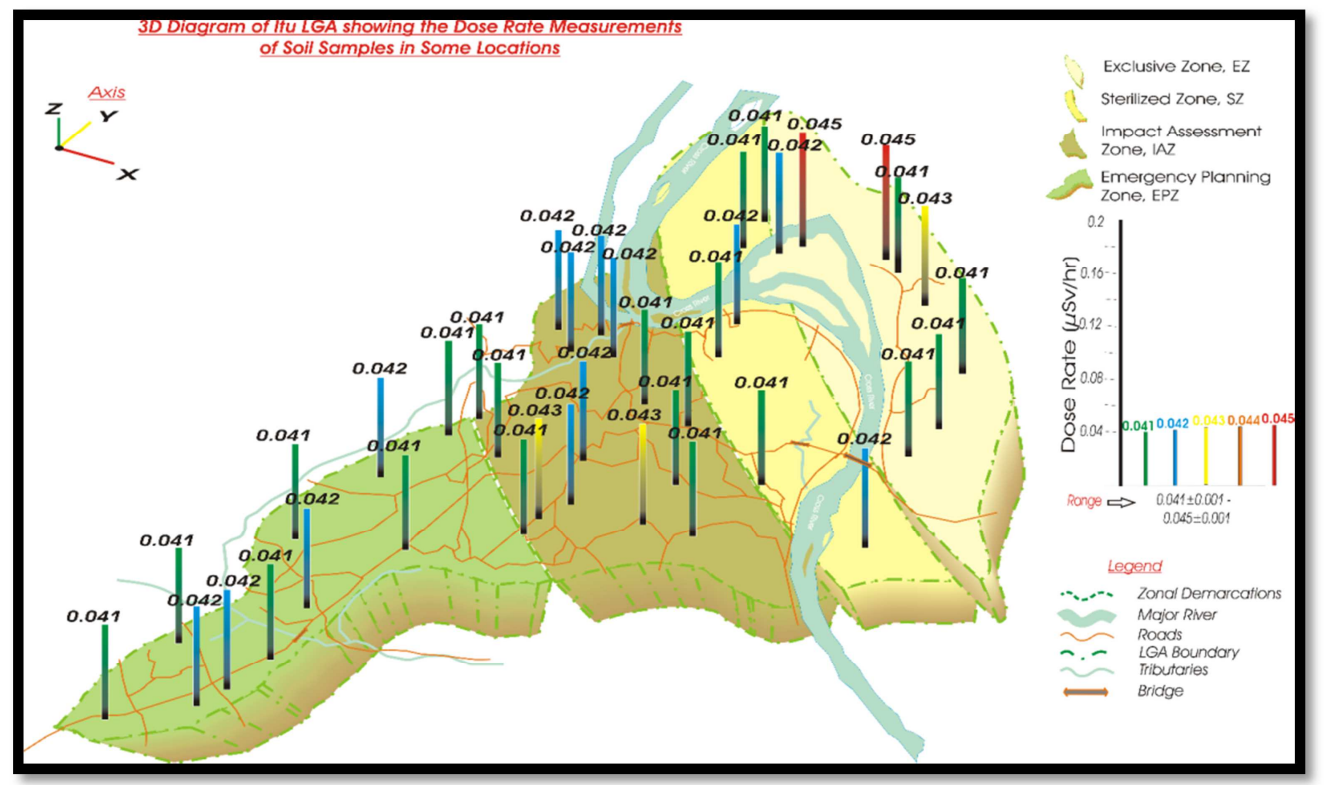

Figure 2. A 3-Dimensional Arc-GIS Map showing the BIR measurements of Itu, Nigeria and the world limit. 


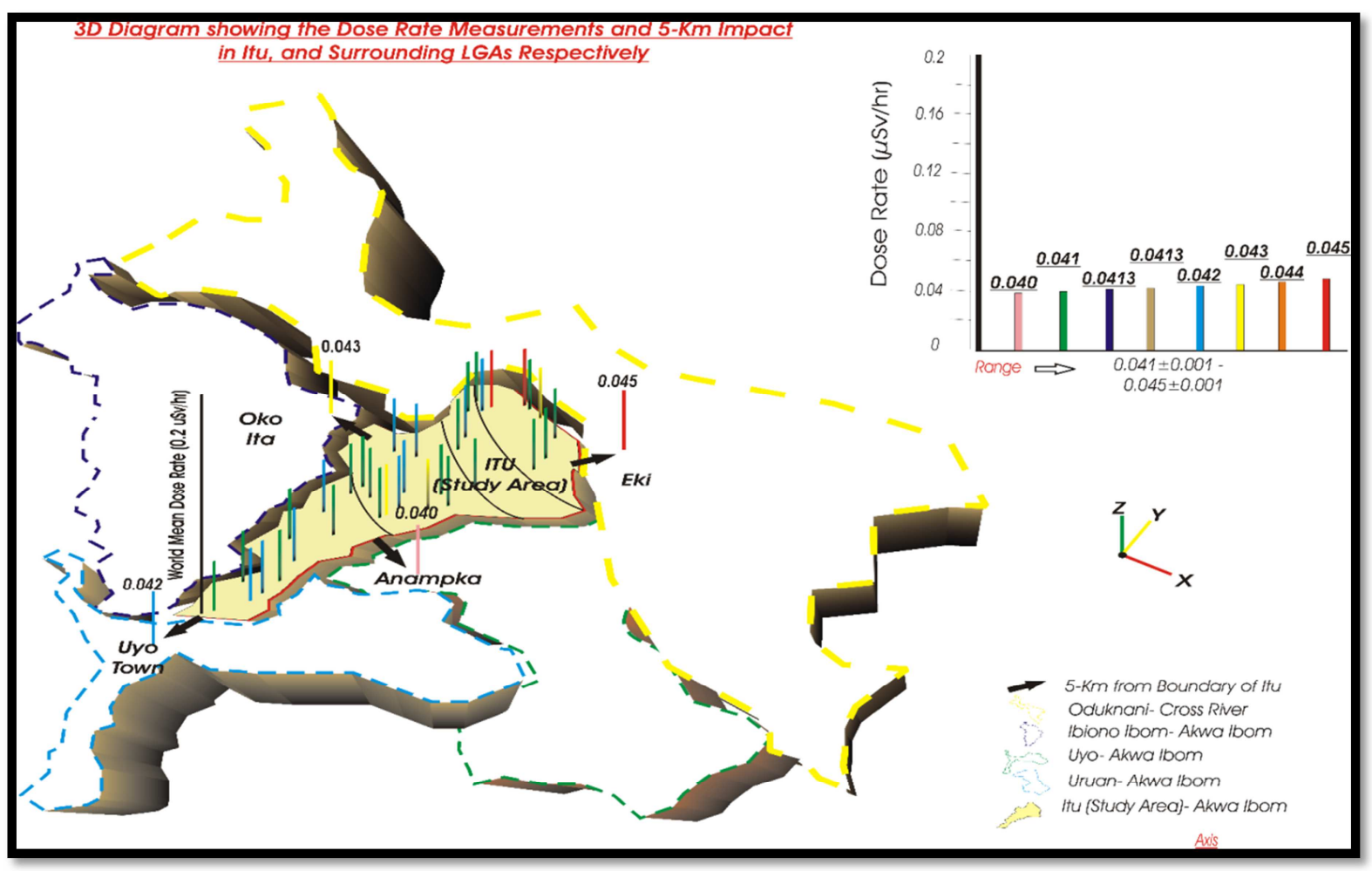

Figure 3. A 3-Dimensional Arc-GIS Map showing the BIR measurements of Itu, Nigeria and $5 \mathrm{~km}$ surrounding cities

\subsection{Discussions - Radiological Hazard Indices}

The average BIR values of $0.042 \pm 002 \mu \mathrm{Sv} / \mathrm{hr}$ presented in Table 1 was found be equivalent of $0.35 \mathrm{mSv} / \mathrm{yr}$ lower than equivalents annual dose stipulated for the public being 1 $\mathrm{mSv} / \mathrm{yr}$ and world average dose rate value of $0.2 \mu \mathrm{Sv} / \mathrm{hr}$, and the radiological hazards indices considerations from BIR measurements were evaluated as presented in Table 1 and a graphical presentation in Figure 4. The measured BIR values were as a result of terrestrial gamma contribution which were within the dose rate measurement of $10 \mathrm{nSv} / \mathrm{hr}$ to about 180 $\mathrm{nSv} / \mathrm{h}$ obtained in the Southern and other regions of Nigeria except for Jos, Plateau State that is about $0.2 \mu \mathrm{Sv} / \mathrm{hr}$ [36] due to mining activities. The calculated GDR arising from terrestrial gamma of BIR measurement for entire four zones of the study area was with mean of $9.312 \mathrm{nGy} / \mathrm{hr}$ which was lower when compared with world mean of $59 \mathrm{nGy} / \mathrm{hr}[32,35]$. Also, the AEDR from both terrestrial outdoor and indoor gamma from absorbed gamma dose rate were subsequently estimated for outdoors with mean value of $6.83 \mathrm{mSv} / \mathrm{yr}$, and the evaluated indoor AEDR with mean value of $21.85 \mathrm{mSv} / \mathrm{yr}$ were within admissible value when compared with world mean of $460 \mathrm{mSv}$. The major reason outdoor AEDR is lower than the AEDR indoor is that more time is spent indoors as well as radiation contributions from building materials. The acceptable annual effective dose for public without any constraint is $1 \mathrm{mSv} / \mathrm{yr}$ for the purpose of safety and with constraint of $0.5 \mathrm{mSv} / \mathrm{yr}[32,33,35]$. Furthermore, the estimated ELCR evaluated was with the mean value of $0.05 \times$ $10^{-3}$, which was lower when compared with world mean value of $0.29 \times 10^{-3}[32,35]$. This means that the likelihood of infant of adult becoming a cancer patient in the study area is very negligible.

Lastly, the various estimated hazard indices within $5 \mathrm{~km}$ from Itu for the four villages/LGAs were all within range values earlier quoted for the different zones in Itu LGA. The radiological hazards indices evaluation from the BIR measurements shows there is no likelihood of any effect of radiation risk or health implications for both humans and other biota through various pathways. However, caution on anthropogenic activities, which is likely increase radiation level in the Itu, Nigeria should be avoided.

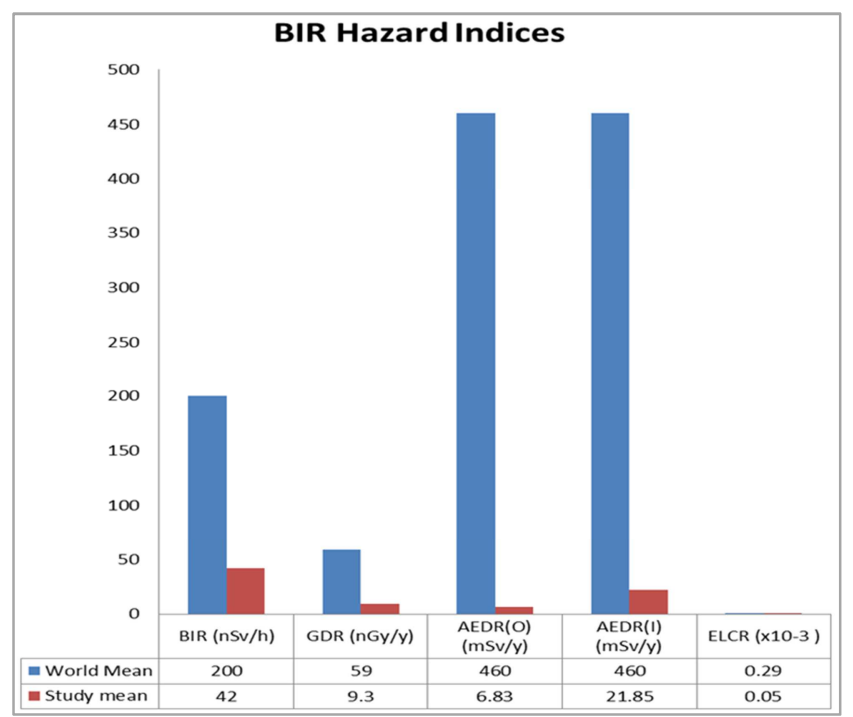

Figures 4. A Radiological hazard indices of the study area in comparison with the world average. 
The average BIR values of $0.042 \pm 002 \mu \mathrm{Sv} / \mathrm{hr}$ was found be equivalent of $0.35 \mathrm{mSv} / \mathrm{yr}$ lower than equivalents annual dose stipulated for the public being $1 \mathrm{mSv} / \mathrm{yr}$ and world average dose rate value of $0.2 \mu \mathrm{Sv} / \mathrm{hr}$ which indicated no human activity for increase radiation level [32, 35]. The measured BIR values obtained in the area of study were as a result of terrestrial gamma contribution which were within the dose rate measurement of $10 \mathrm{nSv} / \mathrm{hr}$ to about $180 \mathrm{nSv} / \mathrm{h}$ obtained in the Southern and other regions of Nigeria except for Jos, Plateau State that is about $0.2 \mu \mathrm{Sv} / \mathrm{hr}$ [36]. Also, the evaluation was attributed to geological formation and geographical location and not natural occurrence radioactive material human activities from the study area.

Some comparison studies conducted in other places compared with this present study were reported. An evaluation of radiation indices and excess life cancer risk within Uyo, Unity Park, Uyo, South-South Nigeria were reported with an average dose rate of $0.116 \mu \mathrm{Sv} / \mathrm{hr}$ [37]. Also, measurements of surface dose rate of nuclear radiation in coastal areas of Akwa Ibom State, an oil producing state of Delta region, South-South Nigeria reported an average dose rate of $0.12 \mu \mathrm{Sv} / \mathrm{hr}(0.012 \mu \mathrm{R} / \mathrm{hr})$ [38]. An in-situ assessment of the indoor and outdoor background radiation was conducted in Akwanga and Keffi towns of Nasarawa state North Central Nigeria for both indoor and outdoor background radiation, and the results showed that in Keffi town were 0.148 $\pm 0.02 \mu \mathrm{Svhr}^{-1}$ and $0.139 \pm 0.02 \mu \mathrm{Svhr}^{-1}$, Akwanga town were $0.176 \pm 0.02 \mu \mathrm{Svhr}^{-1}$ and $0.155 \pm 0.02 \mu \mathrm{Svhr}^{-1}$ for indoor and outdoor background radiation, respectively [39]. Similarly, a measurement of BIR from some selected refuse dumpsites in Yola Metropolis, North-Eastern Nigeria was conducted with the mean background ionizing radiation values in all the five dumpsites as $0.132 \pm 0.021 \mu \operatorname{Svhr}^{-1}\left(0.015 \pm 0.002 \mathrm{mR} / \mathrm{hr}^{-1}\right)$ [40].

Also, in-situ BIR measurements were conducted to assess terrestrial naturally occurring radioactive material in soil and mine tailings in Awo and Ede, Osun-State, South West Nigeria. The result obtained showed a ranged from $0.02 \mu \mathrm{Svhr}^{-1}$ to $0.11 \mu \mathrm{Svhr}^{-1}$ with an average value of 0.06 $\mu \mathrm{Sv} / \mathrm{hr}$ [41]. A study on BIR Assessment of Solid Mineral Mining Sites was conducted in Enugu State, South East Nigeria. The average BIR level recorded in the mining sites in Enugu was $0.156 \pm 0.035 \mu \mathrm{Sv} / \mathrm{hr}\left(0.018 \pm 0.004 \mathrm{mR} / \mathrm{hr}^{-1}\right)$ [42]. However, there are several other places where BIR measurement values were recorded to be above the world average. BIR measurement was carried out three years after the 2011 Tsunami that resulted in NPP accident in Fukushima, Japan with radiation levels in most affected areas recorded within the range of $(0.563 \pm 0.08-$ $22.84 \pm 1.26) \mu \mathrm{Sv} / \mathrm{hr}$. This values were found to be equivalent of $(5-200) \mathrm{mSv} / \mathrm{hr}$ which is higher than equivalents dose stipulated for the public being $1 \mathrm{mSv} / \mathrm{yr}$ and also higher than the world average dose rate value of $0.2 \mu \mathrm{Sv} / \mathrm{hr}[35,43]$.

The BIR measurements enumerated from different parts of Nigeria generally was quite low which fell below the world average as it possesses no threats to both human and environment; this is however with an exception of areas where anthropogenic activities (mining and milling, oil and gas drilling, etc.) are conducted likely pose significant radiological health hazards to the public. It is pertinent to note that the power of data acquisition from the BIR measurements in the entire Itu, Nigeria is grossly adequate and sufficient to be relied upon for consideration as BIR baseline measurement. The tabulated comparison of BIR measurements of this study in Itu, Nigeria and other is presented in Table 2.

Table 2. Comparison of BIR measurements from published reports with the present study.

\begin{tabular}{|c|c|c|}
\hline Locations & BIR Measurements & References \\
\hline $\begin{array}{l}\text { Unity Park, Uyo, Akwa } \\
\text { Ibom Nigeria }\end{array}$ & $0.11 \mu \mathrm{Sv} / \mathrm{hr}$ & {$[37]$} \\
\hline $\begin{array}{l}\text { Coastal Areas of Akwa } \\
\text { Ibom, Nigeria }\end{array}$ & $0.12 \mu \mathrm{Sv} / \mathrm{hr}(0.012 \mu \mathrm{R} / \mathrm{hr})$ & {$[38]$} \\
\hline $\begin{array}{l}\text { Akwanga Nasarawa, } \\
\text { Nigeria (indoor / outdoor) }\end{array}$ & $\begin{array}{l}0.176 \pm 0.02 \mu \mathrm{Svhr}^{-1} / 0.155 \\
\pm 0.02 \mu \mathrm{Svhr}^{-1}\end{array}$ & [39] \\
\hline $\begin{array}{l}\text { Keffi Towns, Nigeria } \\
\text { (indoor and outdoor) }\end{array}$ & $\begin{array}{l}0.148 \pm 0.02 \mu \mathrm{Svhr}^{-1} / 0.139 \\
\pm 0.02 \mu \mathrm{Svhr}^{-1}\end{array}$ & [39] \\
\hline $\begin{array}{l}\text { Awo and Ede, Osun-State, } \\
\text { Nigeria }\end{array}$ & $0.06 \mu \mathrm{Svhr}^{-1}$ & [41] \\
\hline $\begin{array}{l}\text { Solid Mineral Mining } \\
\text { Sites Enugu State }\end{array}$ & $\begin{array}{l}0.156 \pm 0.035 \mu \mathrm{Svhr}^{-1} \\
\left(0.018 \pm 0.004 \mathrm{mR} / \mathrm{hr}^{-1}\right)\end{array}$ & {$[42]$} \\
\hline $\begin{array}{l}\text { Refuse dumpsites in Yola } \\
\text { Metropolis, North - } \\
\text { Eastern Nigeria }\end{array}$ & $\begin{array}{l}0.132 \pm 0.021 \mu \mathrm{Svhr}^{-1} \\
\left(0.015 \pm 0.002 \mathrm{mR} / \mathrm{hr}^{-1}\right)\end{array}$ & {$[40]$} \\
\hline Fukushima, Japan & $\begin{array}{l}(0.563 \pm 0.08-22.84 \pm 1.26) \\
\mu \mathrm{Svhr}^{-}\end{array}$ & {$[43]$} \\
\hline Itu, Nigeria & $0.042 \pm 002 \mu \mathrm{Sv} / \mathrm{hr}$ & Present Study \\
\hline World Average & $0.2 \mu \mathrm{Sv} / \mathrm{hr}$ & {$[17,32,35]$} \\
\hline
\end{tabular}

\section{Conclusions}

Background ionizing radiation measurements conducted in Itu, Nigeria were found to be lower than world mean values, which was an indication of no natural occurrence radioactive material anthropogenic activity except that attributed to geological formations and geographical location of the area. Also, the radiological hazard indices subsequently evaluated were found to be lower than world mean, which poses no significant radiological health threat to the populace. Therefore, the assessment demonstrates that there is no elevated level of dose rate, which is makes it safe for human habitation, but care should be taken to avoid increase radiation level from human activities. It is recommended that constant radiological monitoring be encourage, and the data considered as radiological baseline in Itu, Nigeria.

\section{Acknowledgements}

The lead author acknowledges the institutional support he received from the Nigerian Nuclear Regulatory Authority, Federal Capital Territory, Abuja. The authors are grateful to the anonymous reviewers for their invaluable suggestions.

\section{Conflicts of Interest}

The authors declare no conflict of interest. 


\section{References}

[1] Mikhailovskaya, L. N.; Modorov, M. V.; Pozolotina, V. N.; Antonova, E. V. Heterogeneity of soil contamination by $90 \mathrm{Sr}$ and its absorption by herbaceous plants in the East Ural Radioactive Trace area, Science of the Total Environment. 2019, 651 Part2, 2345-2353.

[2] Ni, Y.; Wang, Z.; Zheng, J.; Tagami, K.; Guo, Q.; Uchida, S.; Tsukada, H. The transfer of fallout plutonium from paddy soil to rice: A field study in Japan, Journal of Environmental Radioactivity. 2019, $196, \quad 22-28$, https://doi.org/10.1016/j.jenvrad.2018.10.010.

[3] Andoh, M.; Yamamoto, H.; Kanno, T.; Saito, K. Measurement of ambient dose equivalent rates by walk survey around Fukushima Dai-ichi Nuclear Power Plant using KURAMA-II until 2016, Journal of Environmental Radioactivity, 2018, 190 191, 111-121, https://doi.org/10.1016/j.jenvrad.2018.09.010.

[4] Giwa, K. W.; Osahon, O. D.; Amodu, F. R.; Tahiru, T. I.; Ogunsanwo, F. O. Radiometric analysis and spatial distribution of radionuclides with-in the terrestrial environment of South-Western Nigeria using ERICA tool, Environmental Nanotechnology, Monitoring \& Management, 2018, 10, 419-426, https://doi.org/10.1016/j.enmm.2018.10.002.

[5] Andoh, M.; Matsuda, N.; Saito, K. Evaluation of ambient dose equivalent rates owing to natural radioactive nuclides in eastern Japan by car-borne surveys using KURAMA-II, Trans. Atom. Energy Soc. Jpn. 2017, 16, 63-80.

[6] Choi, G.-S.; Kim, H.-R.; Han, M.-H. An investigation into radiation levels associated with dismantling the Korea research reactor, Nuclear Engineering and Technology, 2010, 42, 468-473.

[7] Lee, U-J.; Kim, M. J.; Kim, H. R. Radioactive iodine analysis in environmental samples around nuclear facilities and sewage treatment plants, Nuclear Engineering and Technology, 2018, 50, 1355-1363, https://doi.org/10.1016/j.net.2018.07.017.

[8] Sohrabi, M.; Parsouzi, Z.; Amrollahi, R.; Khamooshy, C.; Ghasemi, M. Public exposure from environmental release of radioactive material under normal operation of unit-1 Bushehr nuclear power plant, Ann. Nucl. Energy, 2013, 55, 351-358, doi: 10.1016/j.anucene.2012.12.002.

[9] UNEP. Radiation Effects and Sources: What is Radiation? What does Radiation do to us? Where does radiation come from? New York, 2016, Available at: https://doi.org/10.18356/b1749f17-en.

[10] Emanuele, K.; Lin, Z.; Healey, S.; Shareef, A. R.; Regan, P. Isotopic analysis of plutonium in foods by inductively-coupled plasma mass spectrometry, Appl. Radiat. Isot., 2017, 126, 40-43 https://doi.org/10.1016/j.apradiso.2017.01.043.

[11] Mikhailovskaya, L. N.; Pozolotina, V. N.; Antonova, E. V. Accumulation of $90 \mathrm{Sr}$ by plants of different taxonomic groups from the soils at the East Ural Radioactive Trace. In: Gupta, D. K. and Walther, C. (Eds.), Behaviour of Strontium in Plants and the Environment, Springer International Publishing, Cham, 2018, pp. 61-73.

[12] Sokolik, G. A.; Ovsiannikova, S. V.; Ivanova, T. G.; Leinova, S. L. Soil-plant transfer of plutonium and americium in contaminated regions of Belarus after the Chernobyl catastrophe, Environ. Int. 2004, 30, 939-947.
[13] Wang, Z. T.; Zheng, J.; Tagami, K.; Uchida, S. Newly derived transfer factors for $\mathrm{Th}, \mathrm{Am}, \mathrm{Pu}$, and $\mathrm{Cl}$ since publication of IAEA TRS No. 472: A review, J. Radioanal. Nucl. Chem., 2015, 306, 11-20.

[14] Martínez, J.; Peñalver, A.; Baciu, T.; Artigues, M.; Danús, M.; Aguilar, C.; Borrull, F. Presence of artificial radionuclides in samples from potable water and wastewater treatment plants, Journal of Environmental Radioactivity, 2018, 192, 187-193, https://doi.org/10.1016/j.jenvrad.2018.06.024.

[15] International Atomic Energy Agency (IAEA). Radiation Protection and Safety of Radioactive Source, International Basic Safety Standard, IAEA, Vienna, Austria. General Safety Requirements Part 3, 2014, 1-110.

[16] Wrixon, A. D. New International Committee of Radiation Protection Recommendations, Journal of Radiological Protection, 2008, 28, 161-168.

[17] International Commission on Radiological Protection (ICRP). Application of the Commission's Recommendation to the protection of people in Emergency Exposure Situation, 2007, $39,5-12$.

[18] Mulas, A.; Camacho, A.; Serrano, I.; Montes, S.; Devesa, R.; Duch, M. A. Natural and artificial radionuclides in sludge, sand, granular activated carbon and reverse osmosis brine from a metropolitan drinking water treatment plant, Journal of Environmental Radioactivity, 2017, 177, 233-240, https://doi.org/10.1016/j.jenvrad.2017.07.001.

[19] Fonollosa, E.; Nieto, A.; Peñalver, A.; Aguilar, C.; Borrull, F. Presence of radionuclides in sludge from conventional drinking water treatment plants. A review. J. Environ. Radioact., 2014, 141C, 24-31, doi: 10.1016/j.jenvrad.2014.11.017.

[20] Mamikhin, S. V.; Golosov, V. N.; Paramonova, T. A.; Shamshurina, E. N.; Ivanov, M. M. Vertical distribution of $137 \mathrm{Cs}$ in alluvial soils of the Lokna River floodplain (Tula oblast) long after the Chernobyl accident and its simulation, Eurasian Soil Science. 2016, 49 (12), 1432-1442. doi: $10.1134 / \mathrm{S} 1064229316120103$.

[21] Fujii, M.; Ono, K.; Yoshimura, C.; Miyamoto, M. The role of autochthonous organic matter in radioactive cesium accumulation to riverine fine sediments, Water Research, 2018, 137, 18-27, https://doi.org/10.1016/j.watres.2018.02.063.

[22] Gerzabek, M. H. (2011). Short, medium and long-term effects of radionuclide contamination after a nuclear accident - lesson learnt in Austria from the Chernobil disaster, Annal Agrar. Sci., 2, 45-50.

[23] Jibiri, N. N.; Farai, I. P.; Ogunlana, A. M. Radioactivity Level of Some Nigerian Rock Samples, Nigeria Journal of Physics, 1999, 11, 220-226.

[24] United Nations Scientific Committee on the Effects of Atomic Radiation (UNSCEAR) (2008). Sources and Effects of Ionizing Radiation. New York, USA.

[25] US Environmental Protection Agency (US EPA) (2011). Multi-Agency and Site Survey Investigation Manual.

[26] Youdeowei, T. Nigeria signs pact with Russia on nuclear energy. Vanguard Newspaper Online. 2017, Available online: https://www.vanguardngr.com/2017/11/nigeria-signs-pact-r ussia-nuclear-energy/ (Accessed on November 21, 2018). 
[27] Anuforo, E.; Onyedika, U. N. Nigeria Russia okay pact to build nuclear plants in Kogi, Akwa Ibom States, 2016, Guardian Newspaper. Available online https:/guardian.ng/news/nigeria-russia-okay-pact-to-build-nuc lear-plants-in-kogi-akwa-ibom/ (Accessed on November 21, 2018).

[28] Ayoade, B. O. Adaptation to climate change in agriculture, forestry and fisheries: Perspective framework and priorities, Food and Agriculture Organization of the United Nations Rome, 1998, pp. 149-155.

[29] Ministry of Environment and Forests (MoEF) (2010). Environmental Impact Assessment Guidance Manual - For Nuclear Power Plants, Nuclear Fuel Reprocessing Plants and Nuclear Waste Management Plants, Government of India, New Delhi, India. 7-8.

[30] Ezekiel, A. O. (2017). Assessment of excess lifetime cancer risk from gamma radiationlevels in Effurun and Warri city of Delta state, Nigeria. Journal of Taibah University for Science, $11,367-380$.

[31] United Nations Scientific Committee on the Effects of Atomic Radiation (UNSCEAR), 2000, Effects and Risks of Ionizing Radiations. United. Nations. New York, USA.

[32] Al-Sulaiti, H. Determination of Natural Radioactivity Levels of the State of Qatar Using High-Resolution Gamma - ray Spectrometry. MPhil to PhD Transfer Report, Department of Physics (University of Surrey), 2009.

[33] International Commission on Radiological Protection (1990). The Recommendations of the International Commission on Radiological Protection, ICRP Publication 60, Annals 21, 1-3.

[34] Taskin H.; Karavus M.; Topuzoghi, P. Ay.; Hindiroglu, S.; Karaha G. Radionuclide concentrations in soil and lifetime cancer risk due to the gamma radioactivity in Kirklareli. Journal of Environmental Radioactivity, 2009, 100, 49-53.

[35] United Nations Scientific Committee on the Effects of Atomic Radiation (UNSCEAR) (2000). Exposures from natural radiation sources, Annex B New York, USA.
[36] Nigerian Nuclear Regulatory Authority (NNRA). Establishing Radiological Baseline Data in Nigeria. Nigerian Nuclear Regulatory Authority, Abuja. NNRA Annual Report of 2016, 96-98.

[37] Etuk S. E.; Essiett A. A.; Agbasi, O. E. Measurement of outdoor ambient radioactive radiation and evaluation of radiation indices and Excess Life Cancer Risk within Uyo, Unity Park, Uyo, Nigeria. Journal of Geography, Environmental and Earth Science International, 2017, 9 (4), $1-9$.

[38] Essiett A. A.; Essien I. E.; Bede M. C. Measurement of Surface Dose Rate of Nuclear Radiation in Coastal Areas of Akwa Ibom State, Nigeria. International Journal of Physics, 2015, 3 (5), 224-229.

[39] Ramli, A. T.; Aliyu, A. S.; Agba, E. H.; Saleh, M. A. Effective dose from natural background radiation in Keffi and Akwanga towns, Central Nigeria. International Journal of Radiation Research, 2014, 12 (1), 47-52.

[40] Alkasim, A.; Muhammad, T. B.; Ali, A.; Elvis, G. Measurement of Gamma Radiation from Some Selected Refuse Dumpsites in Yola Metropolis, North - Eastern Nigeria. Journal of Applied Physics, 2017, 9 (5), 13-17.

[41] Adewale, O. O.; Tubosun, I. A.; Ojo, J. O. Assessment Terrestrial Naturally Occurring Radioactive Material in soil and mine tailings in Awo and Ede, Osun-State, South West Nigeria. Ife Journal of Science, 2015, 17 (1), 199-209.

[42] Osimobi, J. C.; Agbalagba, E. O.; Avwiri, G. O.; Ononugbo, C. P.; GIS Mapping and Background Ionizing Radiation (BIR) Assessment of Solid Mineral Mining Sites in Enugu State, Nigeria. Open Access Library Journal, 2015, 2 (10), 1-9.

[43] Ekong, G. B.; Sambo, I.; Sayaidi, S. Determination of Radionuclides Surface Concentration and Radiation level in Fukushima Prefecture, Japan. Modern Environmental Science and Engineering Journal, 2016, 2 (1), 757-764. 